\title{
Survival after severe self poisoning with sodium valproate
}

\author{
Mayur Lakhani and Marion E.T. McMurdo
}

University Department of Clinical Pharmacology, Ninewells Hospital and Medical School, Dundee DD1 9SY, UK.

\begin{abstract}
Summary: A 48 year old patient deliberately poisoned herself with $25 \mathrm{~g}$ of sodium valproate and survived with supportive measures only. This case contradicts the experience of those who advocate aggressive management of such severe overdoses.
\end{abstract}

\section{Introduction}

Although sodium valproate is now widely used as an anticonvulsant, experience of self poisoning with it is limited and there is a lack of reliable data on its effects in overdose (Volans et al., 1983). We describe a patient who survived ingestion of $25 \mathrm{~g}$ of sodium valproate with supportive therapy alone.

\section{Case history}

A 48 year old woman presented 4 hours after deliberate ingestion of a mixed overdose of $25 \mathrm{~g}$ sodium valproate (enteric coated), $40 \mathrm{mg}$ diazepam and $50 \mathrm{mg}$ temazepam, Idiopathic temporal lobe epilepsy had been diagnosed 15 years previously for which she was treated with sodium valproate $500 \mathrm{mg}$ t.i.d. On admission she was drowsy but rouseable, with generalized hypotonicity but no other abnormal physical findings. A 20 litre gastric lavage was performed but no tablets were recovered. Her conscious level gradually deteriorated and 3 hours after admission she was deeply unconscious, and remained so for $\mathbf{3 0}$ hours.

Serum concentration of sodium valproate was $1040 \mu \mathrm{mol} / 1$ at 4.5 hours and $5100 \mu \mathrm{mol} / 118$ hours after ingestion. Electrocardiogram, minute ventilation, arterial blood gases, urea and electrolytes and haematological investigations including clotting studies and platelet counts remained normal throughout.

Liver function tests, with the exception of aspartate transaminase (AST) were normal. The AST level was elevated from day three to day nine after ingestion with a peak value of $69 \mathrm{U} / 1$ on day three. Despite a normal serum calcium a reduction in serum phosphate was observed from day four to day nine, with a minimum value of $0.50 \mathrm{mmol} / 1$ on day five (reference range $0.80-1.55 \mathrm{mmol} / \mathrm{l})$. The patient made a complete recovery and subsequent to psychiatric assessment was discharged from hospital after 11 days.

\section{Discussion}

Although self poisoning among the epileptic population is relatively common (Mackay, 1979), experience with non-barbiturate anticonvulsants is limited. To our knowledge only three fatalities have been described with sodium valproate (Gourru, 1980; Boillot et al., 1981; Schnabel et al., 1984). Coma and respiratory depression, convulsions, transitory disturbance of liver function tests, hypocalcaemia and thrombocytopenia have been described. In the patient we describe, coma did occur but presumably this was due in part to concurrent ingestion of benzodiazepines.

A variety of 'active treatments' for valproate poisoning have been advocated including forced diuresis (ABPI, 1983), naloxone (Steinman et al., 1979), and haemodialysis/haemoperfusion (Mortensen et al., 1983). However, the experience of Volans et al. (1983), Karlsen et al. (1983) and Eeg-Olofsson \& Lindskog (1982) indicate that supportive therapy alone is adequate, even in massive overdose. Volans et al. (1983) question the need for and the evidence of efficacy for more active measures. The survival of our patient lends support to this contention.

This highlights the need for continued reporting and monitoring of outcome in self poisoning with sodium valproate to enable the management of choice to be properly defined.

Correspondence: M. Lakhani, M.B., Ch.B.

Accepted: 22 October 1985 


\section{References}

ASSOCIATION OF BRITISH PHARMACUETICAL INDUSTRY (ABPI). (1983). Data sheet compendium, 586-88.

BOILLOT, A., BOURGEOIS, F., BARALE, F., LENYS, R., DAOUDAL, P. \& DELACOUR, J.L. (1981). Atteinte medullaire mortelle au cours d'une intoxication aigue volontaire par dipropylacetate de sodium. Nouvelle Presse Médicale, 10, 2038.

EEG-OLOFSSON, K. \& LINDSKOG, U. (1982). Acute intoxication with valproate. Lancet, i, 1306.

GOURRU, J.L. (1980). Intoxication aigue massive par le valproate de sodium a propos d'une observation d'intoxication volontaire mortelle. Thesis, Claude Bernard University, Lyon.

KARLSEN, R.L., KETT, K. \& HENRIKSEN, O. (1983). Intoxication with sodium valproate. Acta Medica Scandinavica, 213, 405.
MACKAY, A. (1979). Self poisoning - a complication of epilepsy. British Journal of Psychiatry, 134, 277.

MORTENSEN, P.B., HANSEN, H.E., PEDERSEN, B., HARTMANN-ANDERSON, F. \& HUSTED, S.E. (1983). Acute valproate intoxication: biochemical investigation and haemodialysis treatment. International Journal of Clinical Pharmacological Therapeutics and Toxicology, 21(2), 64.

SCHNABEL, R., RAMBECK, B. \& JANSSEN, F. (1984). Fatal intoxication with sodium valproate. Lancet, i, 221.

STEINMAN, G.S., WOERPEL, R.W. \& SHERARD, E.S. (1979). Treatment of accidental sodium valproate overdose with an opiate antagonist. Annals of Neurology, 6(3), 274.

VOLANS, G.N., BERRY, J.J. \& WISEMAN, H.M. (1983). Overdose with sodium valproate. British Journal of Clinical Practice, Symposium Supplement, 27, 58. 